\title{
ETHICAL AND LEGAL PROBLEMS CAUSED BY COVID-19 PANDEMIC
}

\author{
A.V. Petrov \\ Doctor of Philosophy, Candidate of Law, Professor, senior research scientist of the Department of the ethical, \\ legal and sociological expertise in medicine of Volgograd Medical Research Center, \\ Professor of the Department of philosophy, bioethics and law with a course of sociology of medicine \\ of Volgograd State Medical University, \\ Volgograd,biosoc2008@yandex.ru

\section{D.A. Donika} \\ Adjunct of the Department of management of crime investigation bodies \\ Academy of management of the Ministry of internal Affairs of Russia, \\ Moscow,ddd1993ddd@yandex.ru
}

In the article these are considered ethical and legal problems caused by the ongoing pandemic of the new coronavirus disease (COVID-19). New challenges for health care, economy, education not only revealed rather a high level of stability and mobility, but also showed a poor readiness of response to sudden risks, which had a certain impact on all spheres of life of the whole society. The authors have conducted a brief cross-cultural analysis of the issue basing on data quoted by the international network of UNESCO chairs in bioethics, sessions of the Bioethics Committee within the RF Commission on UNESCO affairs, as well as official open sources of the health care system and judicial sphere of the Russian Federation. Strong reciprocal link of legal risks in the interdisciplinary field of medicine and law are made discernable: on the one hand, introduction of sanitary and hygienic regulations (using of personal protection gear, sanitary processing, maintaining social distance, etc.) are aimed at the realization of the right of protecting the health, while on the other hand they represent a violation of basic human rights. Besides the theoretical approach to the problem of the observance of the constitutional rights of citizens in the pandemic conditions there exists a real threat of their violation due to absence of special mechanisms of their realization in frames of sanitary and hygienic measures with regard to the vulnerable and socially disadvantaged sections in the society. It is made conclusion about necessity of the international collaboration for the purpose of joint decision-making and action in the sphere of health care taking into account an international character of ethical and legal challenges triggered by COVID-19 pandemic, as well as national, economic, cultural and confessional peculiarities.

Key words: COVID-19 pandemic, social institutions, health care, ethical and legal issues, citizens' rights and freedoms.

\section{ЭТИЧЕСКИЕ И ПРАВОВЫЕ ПРОБЛЕМЫ, ВЫЗВАННЫЕ ПАНДЕМИЕЙ COVID-19}

\author{
А.В. Петров \\ Доктор философских наук, кандидат юридических наук, профессор, \\ старший научный сотрудник Отдела этической, правовой и соииологической экспертизы в медицине \\ Волгоградского медииинского научного иентра, профессор кафедры биоэтики, философии и права \\ с курсом социологии медицины, Волгоградский государственный медицинский университет, \\ 2. Волгоград,biosoc2008@yandex.ru
}

\section{Д.А. Доника}

Адъюнкт кафедры управления органами расследования преступлений, Академия управления МВД России, г. Москва, ddd1993ddd@yandex.ru

\footnotetext{
В статье обсуждаются этические и правовые проблемы, вызванные распространением новой коронавирусной инфекции. Здравоохранение, экономика, образование, приняв неожиданный вызов, продемонстрировали не только степень своей устойчивости и мобильности, но и невысокую готовность быстрого реагирования на внезапные риски, что, несомненно, отразилось на всех сферах жизни общества. Авторами проведен краткий кросскультурный анализ рассматриваемой проблемы на основе данных, проведенных Международной сетью кафедр биоэтики ЮНЕСКО панельных сессий «Этические и правовые вызовы пандемии COVID-19», заседания комитета по биоэтике при Комиссии РФ по делам ЮНЕСКО, а также открытых официальных источников системы здравоохранения и правовой сферы РФ. Показана взаимообусловленность правовых рисков в междисциплинарном поле медицины и права: с одной стороны, вводимые санитарно-гигиенические меры (использование средств индивидуальной защиты, санитарная обработка, социальная дистанция и др.) направлены на реализацию права на сохранение здоровья, с другой, - инициируют нарушения основных свобод. Кроме теоретического подхода к проблеме обеспечения конституционных прав в условиях пандемии, существует и реальная угроза их нарушения вследствие отсутствия специальных
} 
механизмов их реализации с соблюдением санитарно-гигиенических мер к социально незащищенным группам населения. Сделан вывод о необходимости международной коллаборации для выработки совместных решений в области здравоохранения, в связи с интернациональным характером этических и правовых проблем, вызванных пандемией COVID-19, с учетом национальных экономических, культурных, конфессиональных особенностей.

Ключевые слова: пандемия COVID-19, социальные институты, здравоохранение, этические и правовые проблемы, права и свободы граждан.

The pandemic of the newly registered coronovirus infection has become a serious challenge for all social institutions. Health care, economics, education responding to new challenges demonstrated besides their stability and mobility a poor readiness to react in cases of sudden emergency $[3,8]$. This certainly had an impact on each and every sphere of social life. Ethical and legal problems caused by COVID-19 pandemic have become a consequence of social institutions inadequacy in critical situations.

Within the frames of panel sessions held by the International network of Chairs in bioethics of UNESCO (since March 2020 up till now), there were defined ethical and legal challenges caused by COVID-19 pandemic in health care systems at the global level. It was made possible thanks to participation of over 420 leading specialists in the sphere of bioethics and medical law from different countries, such as Australia, Germany, India, Israel, Kenya, Great Britain and the United States of America in on-line discussions concerning the issue $[1,4]$.

As Professor Russell D'Souza (Melbourne) has rightly stated, after the World Health Organization announced COVID-19 outbreak a pandemic on March 11, 2020 the world faced an unprecedented crisis concerning ethical and legal issues at the political level. He pointed out that justice and public health are closely interconnected. Hence the balance between the needs of public health care and civil rights, as well as social impact on government decision making, incites grave political and ethical problems in many countries.

Professor Ilana Belmaker (Israel) spoke about the broad public response to the government decision on limiting freedoms of elderly population in view of the position of orthodox Jews living with their large families in poor communities. As a direct consequence of the introduced practice of quarantine of "hotspots", part of the population avoided seeking medical attention from medical institutions for fear of penalty for violating quarantine regulations

Professor Mariom Mutugi (Kenya) dwelled on the disparity between medical awareness, social attitudes and practice. She highlighted cultural aspects, funeral ceremony, in particular, as mourning and burial rites are extremely important in African countries. In most African countries the potential of testing is low. This causes a certain stigmatization. The decision making on resources' distribution should be taken on ethical principles. Besides, Professor M. Mutugi called journalists of medical media to act in compliance with ethics while using statistics data and fake news.

Professor Joseph Thornton from University of Florida, USA, said that serious contradictions about resources' distribution in COVID-19 conditions have been revealed in the USA.

Professor Vivienne Harpwood (She chairs the Welsh NHS Confederation, GB) pointed out that the law on coronavirus triggered a controversial response in the society due to the limitation on personal autonomy. From the bioethics viewpoint, the most socially vulnerable groups: homeless people, cancer patients and patients suffering from psychiatric disorders arouse particular concern.

In the course of a series of panel webinars the conclusion was made about the necessity of providing at the governmental level at least four positions in the sphere of the public health care: planning policy in the face of uncertainty and properly responding to unparalleled challenges, protecting health care workers and taking appropriate actions to improve medical services.

An open session of the Bioethics Committee within the RF Commission on UNESCO affairs was held online 30.04.2020 where ethical and psychological aspects of coronavirus infection pandemic were discussed. Yury Zinchenko, President of the Russian psychological society during his presentation pointed out, in particular, that COVID-19 pandemic revealed national problems of legal regulation of psychological assistance to different social groups, among them medical staff.

Alexander Chouchalin, Academician of the Russian Academy of Sciences, pointed out the difficulty in expressing empathy towards patients for doctors wearing personal protective equipment, which makes it difficult even to communicate verbally. Vladimir Mendelevich attracted attention to the necessity of providing psychological assistance not only to the population in the conditions of the imposed informatization and self-isolation but also to medical workers who provide medical assistance to Covid-19 patients, which causes unprecedented physical and emotional stress.

The introduction of regulations aimed at halting the spread of COVID-19 led, in its turn, to changing the activities of the major social institutions in Russia, including law enforcement, due to extrapolation of medical (sanitary and hygienic) measures. In the sphere of judicial problems an ongoing and especially heated debate concerns different aspects of human rights violation as a consequence of restrictive policies introduced by practically all governments all over the world in conditions of COVID-19 pandemic. 
The current situation demonstrates the importance of compliance and effective implementation of civil, political, economic, social and cultural human rights though mass media of many countries keep commenting on numerous violations of these rights. Not only the issue of restrictions on freedoms is focused on, but the issue of implementation of electronic surveillance of the population is concentrated on too.

On the one hand, the introduced sanitary and hygienic measures (requirement for personal protective equipment, sanitary processing, social distance) are aimed at realization of the right to protecting the health; on the other hand it initiates debate on basic human rights violation. Besides the theoretical approach to the issue of ensuring the constitutional rights in pandemic conditions there exists a real risk of their violation, as there exist no specific mechanisms of their realization in compliance with sanitary and health requirements for certain groups of population.

Among other things, the Russian Federal Bar Association called regional rights activists to file petitions or complains on changing measures of restraint to others than detention in custody, especially for elderly people and for those suffering from chronic diseases.

Moscow lawyers were the first to propose to simplify the process of mass appeals with a standard template where "high risks of spread of the new coronavirus infection among elderly people and those suffering from chronic diseases" is emphasized.

The official site of the Russian Federal Bar Association published an address in April 2020, which read, in part: "if law-enforcement institutions work not only for reporting but for ensuring a true security of citizens we don't see any reason why they could deny such lawyers' petitions satisfaction» [3]. Along with that lawyers referred to the experience of some European countries where imposing preventive measures does not necessarily mean confinement in pre-trial detention facilities.

The official site of the Russian Federal Bar Association also refers to the words of Vadim Klyuvgant, vice-chairman of the Lawyers Rights Protection Commission (the Moscow Chamber of Attorneys) who expresses the hope that "in the current situation Prosecutor's Offices, as well as other law enforcement institutions shall support as priorities the protection of human rights of people not found guilty but detained in custody, as it takes place in other countries" [9].

Another public law organization for human rights protection "The Public Verdict Foundation" called on the government and the Federal Penal Correction Service to be publicly transparent in respect of implementation of control measures against the spread of the coronavirus infection in places of deprivation of liberty.

Human rights activists suggested that the amnesty granted on the occasion of the celebration of the $75^{\text {th }}$ anniversary of the Victory in the Great Patriotic War should become one of the effective tools of reducing the prison population. Other mechanisms were suggested to be implemented at the pre-trial stage to provide security of the participants in criminal proceedings; beginning with April 2020, the proceedings of all criminal cases were halted because of the risks of coronavirus infection spread, according to the decision of the Supreme Court of the Russian Federation.

Exceptions were made only for urgent court proceedings, among them decisions on the selection, extension, change of a preventive measure, cancellation of a measure of restraint; on protection of minors' and legally incompetent individuals' interests in case of refusal of a parent or other legal representative from vitally needed medical intervention [2, 4]. Such kind of a moratorium doesn't concern hearing cases in writ (summary) simplified proceedings either. Furthermore, to ensure the realization of restrictive measures due to pandemic public access to the courts for the visitors who are not parties to judicial proceedings is strictly limited.

The Supreme Court of the Russian Federation recommends to all courts to shift towards hearing cases using systems of video conferencing to the extent possible. Petitioners are supposed to apply be electronic documents via courts' electronic (online) reception centers or by Russian Post [5, 7]. It goes without saying that implementation of such regulations requires a prompt legislative initiative, especially in view of the prognosis of the second wave of COVID-19 [1, 6].

To sum it up COVID-19 pandemic triggered a range of ethical and legal problems characterized by specific economic, cultural, confessional peculiarities, which require international collaboration for joint decision making in the sphere of health care $[4,5]$.

\section{REFERENCES}

1. Bychkova O. I. Ethics and law in the relationship between doctor and patient in military medicine. Military Medical Journal, 2018, vol. 339, no. 9, pp. 11-15. (In Russ.).

2. Goldin Yu.A. Bioethical dilemmas associated with the patient's vulnerability. International Journal of Experimental Education, 2017, no. 4-1, pp. 52-53. (In Russ.).

3. Donika A.D., Petrov A.V. Features of the assessment of legal norms and ethical dilemmas by students of a medical university. Medical Law, 2019, no. 6, pp. 44-48. (In Russ.).

4. Donika D.A. On the issue of abuse of law as a problem in criminal procedural science. Bulletin of the East Siberian Institute of the Ministry of Internal Affairs of Russia, 2020, no. 2 (93). pp. 132-143. (In Russ.).

5. Donika D.A. Abuse of subjective law as a violation of constitutional rights in criminal proceedings. Modern criminal procedural law - lessons of history and problems of further reform, 2019, vol. 1, no. 1 (1), pp. 198-207. (In Russ.).

6. Trubnikova T.V. Everyone's constitutional right to judicial protection of his rights and freedoms and the right to a fair trial: correlation and place in the criminal process of the Russian Federation. Law and Life, 2010, no. 143 (5), pp. 115-127. (In Russ.).

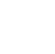


7. The initiative is subject to scaling throughout the country [Electronic resource]. URL: https://fparf.ru/news/ fpa/initsiativa-podlezhit-masshtabirovaniyu-na-vsyu-stranu (date accessed: 05.20.2020). (In Russ.).

8. Coronavirus forced Russian judges to suspend the consideration of cases. [Electronic resource]. URL: https://pasmi.ru/archive/262546 (date of access: 20.05.2020). (In Russ.).

9. Official site of the Federal Chamber of Lawyers of Russia [Electronic resource]. URL: https://fparf.ru (date of access: 20.05.2020). (In Russ.).

\section{ЛИТЕРАТУРА}

1. Бычкова, О.И. Этика и право в отношениях врача и пациента в военной медицине / О.И. Бычкова // Военномедицинский журнал. - 2018. - Т. 339, № 9. - С. 11-15.

2. Голдин, Ю.А. Биоэтические дилеммы, связанные с уязвимостью пациента / Ю.А. Голдин // Международный журнал экспериментального образования. 2017. - № 4-1. - С. 52-53.

3. Доника, А.Д. Особенности оценки правовых норм и этических дилемм студентами медицинского вуза / А.Д. Доника, А.В. Петров // Медицинское право. - 2019. № 6. - С. 44-48.

4. Доника, Д.А. К вопросу злоупотребления правом как проблеме в уголовно-процессуальной науке /
Д.А. Доника // Вестник Восточно-Сибирского института Министерства внутренних дел России. - 2020.№ 2 (93). - С. 132-143.

5. Доника, Д.А. Злоупотребление субъективным правом как нарушение конституционных прав в уголовном судопроизводстве / Д.А. Доника // Современное уголовно-процессуальное право - уроки истории и проблемы дальнейшего реформирования. - 2019. - Т. 1, № 1 (1). - С. 198-207.

6. Трубникова, Т.В. Конституционное право каждого на судебную защиту его прав и свобод и право на справедливое судебное разбирательство: соотношение и место в уголовном процессе РФ / Т.В. Трубникова // Право и жизнь. - 2010. - № 143 (5). - С. 115-127.

7. Инициатива подлежит масштабированию на всю страну [Электронный ресурc]. - URL: https://fparf.ru/news/ fpa/initsiativa-podlezhit-masshtabirovaniyu-na-vsyu-stranu (дата обращения: 20.05.2020).

8. Коронавирус заставил российских судей приостановить рассмотрение дел. [Электронный ресурс]. URL: https://pasmi.ru/archive/262546 (дата обращения: 20.05.2020).

9. Официальный сайт Федеральной палаты адвокатов России [Электронный ресурс]. - URL: https://fparf.ru (дата обращения: 20.05.2020).

\title{
DEVELOPMENT TENDENCIES OF THE INCLUSIVE EDUCATION SYSTEM AT HIGHER MEDICAL SCHOOL: ADAPTATION, MAINTENANCE, PROFESSIONAL READINESS
}

\author{
A.N. Zholudova \\ Candidate of Pedagogy, Associate Professor, Associate Professor of the Department of Psychology, \\ Pedagogy and Inclusive Education of the FAE Ryazan State Medical University after Academician I. Pavlov, \\ Ryazan, a.n.zholudova@yandex.ru
}

\section{D.N. Os'kin}

Associate Professor, Head of the Resource Educational and Methodological Center for the Training of Disabled and Persons with Disabilities, Dean of the FAE of the Ryazan State Medical University after Academician I.P. Pavlov, Ryazan,doctorozzz@gmail.com

\section{O.V. Polyakova}

Candidate of Pedagogy, Associate Professor, Associate Professor of the Department of Psychology, Pedagogy and Inclusive Education, FAE Ryazan State Medical University after Academician I.P. Pavlov, Ryazan,kpptso@bk.ru

\section{E.G. Vershinin}

Candidate of Medicine, Assistant professor, Head of the Department of Medical rehabilitation and sports medicine, Head of the Inclusive Education, Volgograd State Medical University,

Volgograd,werschinin_eugen@list.ru

This article considers the issues of adaptation and organization of the educational process, barrier-free environment and readiness for professional activity of students with disabilities in inclusive education in conditions of inclusive education in a medical university. The relevance of this work is determined by one of the priority areas of state policy in the field of higher education - access to higher education for people with disabilities in inclusive education. Inclusive education at the university is designed to ensure not only the realization of the right of students with disabilities in inclusive education to higher education, but also to solve the problems of socialization and professional demand for such people. In order to improve the process of introducing inclusive education at the Ryazan State Medical University named after Academician I.P. Pavlov, a study was conducted, the main problems and ways of solving them were identified, related to the organization of 